\title{
Tantangan dan strategi peningkatan ekspor produk halal Indonesia di pasar global
}

\author{
Risa Qoni'ah* \\ Deputi Bidang Perniagaan dan Industri, Kementerian Koordinator Bidang Perekonomian, \\ Jakarta, 10710, Indonesia.
}

\begin{abstract}
ABSTRAK
Meskipun Indonesia memiliki penduduk muslim terbanyak di dunia, hal ini belum menjadikan Indonesia sebagai produsen terbesar produk halal. Padahal potensi pertumbuhan industri halal semakin meningkat seiring bertambahnya jumlah penduduk muslim dunia. Beberapa tantangan yang dihadapi dalam upaya meningkatkan ekspor produk halal Indonesia adalah (i) kurang fokus dalam pengembangan produk halal, karena masih mengutamakan ekspor komoditas pertambangan dan perkebunan, (ii) adanya pesaing dari negara non-muslim yang mengembangkan industri halal, dan (iii) Kurangnya pemahaman pelaku UMKM tentang pentingnya sertifikasi halal. Oleh karena itu, strategi yang perlu dilakukan antara lain (i) peningkatan daya saing produk halal indonesia, (ii) memaksimalkan akses pasar ekspor produk halal dengan mengoptimalkan peran dari perwakilan pemerintah di luar negeri, mengikutsertakan UMKM pada pameran di luar negeri dan memanfaatkan perjanjian perdagangan internasional, (iii) mendukung UMKM ekspor dalam rantai pasok global, dan (iv) optimalisasi penggunaan e-commerce dengan memberikan pelatihan, dan pendampingan kepada pelaku UMKM agar dapat mengakses pasar digital.
\end{abstract}

Kata kunci: Ekspor, Halal, Produk, Strategi, Tantangan, UMKM.

(C) 2022 Pusat Kajian Halal ITS. All rights reserved.

\section{Pendahuluan}

Indonesia merupakan negara dengan penduduk muslim terbanyak di dunia. Menurut laporan dari The Royal Islamic Strategic Studies Centre (RISSC) atau MABDA bertajuk The Muslim 500 edisi 2022 , jumlahnya mencapai 231,06 juta penduduk atau setara dengan $86,7 \%$ dari total penduduk Indonesia [1]. Tentu hal ini menjadi potensi besar dalam mengembangkan produk dan jasa yang berbasis jaminan halal. Pemerintah juga berkomitmen untuk mendukung pengembangan produk halal dengan terbitnya Undang-Undang Nomor 33 Tahun 2014 tentang Jaminan Produk Halal. UU tersebut bertujuan untuk memberikan perlindungan dan jaminan kehalalan suatu produk yang dikonsumsi oleh masyarakat. Selain itu, telah disusun pula masterplan pengembangan ekonomi syariah yang mencakup industri halal seperti makanan dan minuman halal, pariwisata halal, fesyen muslim, media dan rekreasi halal, farmasi dan kosmetika halal dan energi terbarukan [2].

\footnotetext{
* Corresponding author. Tel: +62 81392325566; Fax:-.

Email address: risa0304@gmail.com
} 
Sejak adanya pandemi covid-19 yang terjadi sejak akhir tahun 2019 lalu, terjadi penurunan permintaan dunia terhadap industri halal. Berdasarkan laporan Ekonomi Islam Global 2020/2021, pandemi diprediksi telah menurunkan pengeluaran muslim dunia sebesar $8 \%$ di banyak industri halal antara lain sektor keuangan, fashion, kosmetika, farmasi, dan perjalanan wisata. Namun demikian, tahun 2021 diprediksi seluruh sektor tersebut dapat bangkit kecuali untuk perjalanan wisata [3]. Selain itu, pandemi covid-19 juga telah mendisrupsi perekonomian global. Berdasarkan laporan Bank Dunia, perekonomian dunia terkontraksi sebesar $8,9 \%$ yang merupakan penurunan terbesar sejak adanya krisis keuangan global di tahun 1998 [4]. Senada dengan hal tersebut, menurut data Badan Pusat Statistik (BPS) Indonesia juga mengalami penurunan ekonomi akibat covid-19 sebesar 5,32\% di triwulan II 2020 (y-o-y). Namun demikian, neraca perdagangan Indonesia di tahun 2020 tercatat mengalami surplus sebesar USD 21,74 miliar, hal ini didorong adanya peningkatan ekspor yang lebih besar dibandingkan impor [5].

Kinerja neraca perdagangan Indonesia dengan negara Organisasi Kerja Sama Islam (OKI) juga menunjukkan kinerja yang positif. Berdasarkan data dari Kementerian Perdagangan, selama periode Januari - Agustus 2020 tercatat surplus sebesar USD 2,46 miliar serta mampu membukukan nilai ekspor sebesar USD 12,43 miliar [6]. Dari nilai tersebut, produk ekspor tertinggi adalah minyak kelapa sawit sebesar $23,88 \%$, batubara sebesar $9,56 \%$ dan bagian kendaraan bermotor sebesar 3,95\%. Menteri Perdagangan menyampaikan bahwa mayoritas penduduk negara OKI adalah muslim, sehingga permintaan akan standar produk halal cukup tinggi [7].

Selain itu, dengan potensi jumlah penduduk muslim dunia yang terus meningkat dan diperkirakan mencapai 2,2 miliar orang, maka peluang dan pangsa pasar produk halal akan terus bertambah. Namun demikian, menurut laporan State of Global Islamic Economy Report 2019/2020 Indonesia masih menjadi negara dengan peringkat 1 untuk konsumen makanan halal, peringkat 2 untuk konsumsi kosmetik halal dan peringkat 4 untuk konsumen obatobatan halal [2]. Oleh karena itu, penelitian ini bertujuan untuk menganalisa tantangan yang dihadapi dalam mengembangan produk ekspor serta strategi peningkatan ekspor produk halal Indonesia di pasar global. Hasil penelitian ini diharapkan dapat menjadi bahan masukan dalam pengambilan kebijakan pemerintah terkait dengan pengembangan produk halal Indonesia.

\section{Kajian pustaka dan metode penelitian}

\subsection{Kajian pustaka}

\section{Produk halal}

Menurut Majelis Ulama Indonesia, produk halal didefinisikan sebagai produk yang dibuat menggunakan bahan halal dan memenuhi persyaratan thayyib di fasilitas yang tidak terkontaminasi dengan barang haram dan najis [8]. Sedangkan thayyib dapat diartikan sebagai sesuatu yang baik, suci atau bersih dan tidak membahayakan kesehatan apabila dikonsumsi. Badan Penyelenggara Jaminan Produk Halal (BPJPH) juga menyebutkan bahwa berdasarkan Undang-undang Nomor 33 Tahun 2014 Tentang Jaminan Produk Halal (JPH), produk halal adalah barang dan/atau jasa yang terkait makanan, minuman, obat, kosmetik, produk kimiawi, produk biologi, produk rekayasa genetik, serta barang yang digunakan, 
dipakai atau dimanfaatkan oleh masyarakat yang telah dinyatakan halal sesuai dengan syariat Islam.

Sedangkan untuk dikategorikan sebagai produk halal, terdapat 3 (tiga) kriteria yang harus dipenuhi yaitu (i) berdasarkan zat dan kandungannya, (ii) berdasarkan cara memperolehnya dan (iii) berdasarkan cara proses pengolahannya [9]. Senada dengan hal tersebut, Apriantono [10] menyebut bahwa kriteria makanan dan minuman halal yang harus dipenuhi adalah (i) tidak mengandung bahan yang diharamkan menurut hukum Islam, (ii) tidak menggunakan peralatan yang terkena sesuatu yang haram dalam tahap persiapan, pembuatan dan penyimpanan, dan (iii) tidak terkontaminasi dengan sesuatu yang haram dalam proses persiapan, pembuatan, penyimpanan dan distribusi.

Selain itu, untuk memperoleh produk halal, perlu diperhatikan tahapan pembuatan produk tersebut mulai dari pengadaan bahan, baik bahan baku, bahan tambahan maupun bahan penolong, penyimpanan bahan, proses pengolahan, pengemasan produk, pendistribusian, penjualan serta penyajian produk kepada konsumen [11]. Dalam Undang-Undang Jaminan Produk Halal (JPH) juga disebutkan bahwa bahan yang digunakan dalam proses pembuatan produk halal dapat berasal dari hewan, tumbuhan maupun bahan yang dihasilkan dari proses kimiawi, biologi dan rekayasa genetik, namun semua bahan tersebut harus telah mendapatkan sertifikasi halal [12]. Merdesci [13] juga dalam penelitiannya menyimpulkan bahwa pangan baik adalah makanan yang memiliki cita rasa yang baik, kandungan gizinya baik serta memiliki hiegenitas yang baik. Hal ini karena setiap muslim diwajibkan mengkonsumsi produk yang terjaga kehalalannya.

\section{Sertifikasi halal}

Menurut Peraturan Pemerintah Nomor 39 Tahun 2021 tentang Penyelenggaraan Bidang Jaminan Produk Halal, sertifikat halal adalah pengakuan kehalalan suatu produk yang dikeluarkan oleh Badan Penyelenggara Jaminan Produk Halal (BPJPH) berdasarkan fatwa halal tertulis yang dikeluarkan oleh Majelis Ulama Indonesia (MUI) [14]. Secara teknis, otoritas yang menerbitkan sertifikat halal adalah Lembaga Pengkajian Pangan, Obat-Obatan dan Kosmetika (LPPOM) yang juga merupakan Lembaga Pemeriksa Halal (LPH). Sehingga terdapat 3 (tiga) Lembaga yang berperan dalam menangani sertifikasi halal di Indonesia, yaitu BPJPH, LPH dan MUI [15]. Adapun tujuan dari sertifikasi halal adalah adanya pengakuan secara legal formal bahwa produk tersebut telah memenuhi persyaratan dan ketentuan halal, sehingga aman dan dapat dikonsumsi oleh masyarakat [16].

Selain itu, dengan adanya sertifikasi halal, maka terjamin kepastian kehalalan dan ada perlindungan terhadap konsumen dan produsen atas produk yang beredar dan dikonsumi oleh masyarakat, seperti makanan, minuman, obat-obatan, kosmetika dan produk halal lainnya. Sedangkan untuk produsen produk, sertifikasi merupakan bentuk pertanggungjawaban atas produk yang diproduksi kepada konsumennya, dapat meningkatkan kepercayaan dan kepuasan masyarakat, dapat meningkatkan daya saing produknya dan dapat meningkatkan nilai jual produknya karena telah memenuhi standar halal.

Hasil dari kegiatan sertifikasi halal biasanya dibuktikan dengan diterbitkannya sertifikat halal. Kamsari [17] menyebut bahwa sertifikasi halal menganut system tracebility atau sistem ketertelusuran dan bukan merupakan "end product analysis". Sistem ketertelusuran dimaksudkan untuk melacak seluruh proses produksi mulai dari pembuatan hingga 
pendistribusian atau di sepanjang rantai pasoknya [18]. Hal ini penting guna meningkatkan transparansi produk halal agar tidak terkontaminasi dengan barang yang haram dikomsumsi oleh konsumen.

Dalam rangka memudahkan konsumen dalam melihat sertifikat halal suatu produk, biasanya dicantumkan dengan label halal di kemasan produk. Labelisasi halal merupakan penulisan atau pencantuman logo halal pada kemasan produk untuk menunjukkan bahwa produk tersebut halal statusnya [19]. Pelaku usaha diwajibkan mencantumkan label halal pada kemasan produknya di bagian tertentu yang mudah dilihat, tidak mudah dihapus atau rusak. Hal ini menunjukkan apabila pelaku usaha tidak mencantumkan logo halal, maka akan terkena sanksi administratif berupa teguran lisan, peringatan tertulis dan pencabutan sertifikasi halal [20].

\section{Ekspor impor produk halal Indonesia}

Meski memiliki jumlah penduduk muslim terbanyak di dunia, Indonesia belum menjadi ekspotir terbesar produk halal dunia. Menteri Perdagangan menyampaikan bahwa kinerja ekspor halal Indonesia masih tertinggal dibandingkan negara lainnya [6]. Sebagai contoh, ekspor produk halal, peringkat Indonesia berada di urutan 20 dunia dengan pangsa pasar hanya 1,86\%. Namun demikian, selama periode 2015-2019, perkembangan ekspor produk makanan asal Indonesia ke negara OKI meningkat sebesar 5,51\%. Selama periode Januari Juli 2020, nilai ekspornya mencapai USD 454,16 juta. Hal ini menujukkan bahwa produk Indonesia makin digemari oleh masyarakat luar negeri.

Sedangkan untuk ekspor produk kosmetik, ekspotir utamanya adalah Perancis dengan pangsa pasar 17,38\%, Amerika Serikat 7,57\%, dan Jerman 7\%, sedangkan Indonesia berada di peringkat 19 dunia, dengan pangsa pasarnya hanya 1,21 persen, jauh dibawah pangsa pasar Singapura yang mencapai 5,87 persen [7]. Ekspor produk kosmetik asal Indonesia selama periode 2015-2019 tercatat menurun tipis sebesar 0,77\%. Oleh karena itu, perlu adanya strategi yang efektif meningkatkan nilai ekspor dan pangsa pasar produk Indonesia.

Untuk produk obat-obatan, eksportir utama ke negara OKI adalah Jerman, Perancis dan Swiss dengan pangsa pasar masing-masing sebesar 13,84 \%, 13,58\% dan 9,47\%. Indonesia sendiri menempati peringkat 48 dunia dengan pangsa pasar sebesar 0,12\%. Meski demikian, ekspor produk obat-obat pada periode Januari-Juli 2020 senilai USD 31,31 juta atau meningkat $12,33 \%$ dibandingkan periode yang sama tahun 2019. Sementara itu, pada periode JanuariJuli 2020, Indonesia juga masih mengimpor produk obat-obat sebesar USD 5,5 juta, sehingga Indonesia mampu mencetak surplus necara perdagangan sebesar USD 25,81 juta [21].

\subsection{Metode penelitian}

Penelitian ini merupakan penelitian deskriptif dengan tujuan untuk menggali informasi lebih dalam mengenai tantangan yang dihadapi dalam meningkatkan ekspor Indonesia, khususnya produk halal serta upaya untuk meningkatkan ekspornya. Hal ini karena penelitian deskriptif merupakan penelitian yang menjelaskan detail situasi, kondisi dan informasi suatu kejadian atau peristiwa [22]. Penelitian menggunakan data sekunder yang berasal dari artikel ilmiah, publikasi lembaga pemerintah maupun Lembaga internasional dan dokumen lainnya. Data yang didapat dari berbagai sumber tersebut kemudian dilakukan analisa dengan menghasilkan penjelasan deskriptif berupa narasi, gambar, maupun simbol-simbol. 
Analisa data yang dilakukan dalam penelitian ini terdiri dari 3 (tiga) tahapan, yaitu mereduksi data, melakukan kategorisasi data, dan verifikasi data. Data yang ada kemudian diseleksi, dipilah dan disederhanakan sesuai dengan objek penelitian yaitu tantangan dan strategi dalam pengembangan ekspor produk halal. Setelah itu dilakukan kategorisasi data yang sudah direduksi untuk selanjutnya diverifikasi dan diambil kesimpulan yang merupakan suatu interpretasi dari data tersebut [23].

\section{Hasil dan pembahasan}

\section{Tantangan yang dihadapi dalam mengembangkan produk halal}

Industri halal selama beberapa dekade terakhir terus berkembang pesat. Berdasarkan laporan dari The International Trade Centre, peluang sektor makanan dan miniman halal diperkirakan senilai USD 1 triliun dan diperkirakan akan terus meningkat pertumbuhannya [24]. Hal ini didorong oleh meningkatnya kebutuhan dan preferensi penduduk muslim dunia. Namun demikian, sebagai penduduk dengan muslim terbesar, Indonesia belum menjadi market leader produsen dan pengekspor produk halal. Hal ini menunjukkan masih terdapat beberapa tantangan yang dihadapi dalam upaya peningkatan ekspor produk halal, yaitu:

a. Kurang fokus dalam pengembangan produk halal

Komoditas unggulan ekspor Indonesia hingga saat ini masih didominasi oleh komoditas yang berbasis pertambangan, dan perkebunan. Berdasarkan data dari Badan Pusat Statistik, komoditas utama ekspor nonmigas Indonesia adalah lemak dan minyak hewan/nabati; bahan bakar mineral; serta besi dan baja. Pada periode Triwulan III-2021, ekspor non migas Indonesia mencapai USD 58 miliar, yang terdiri dari sektor industri pengolahan (USD 46,6 miliar), pertambangan (USD 10,7 miliar) dan pertanian (USD 1 miliar) [25].

Saat ini produk halal Indonesia yang telah diekspor ke mancanegara adalah produk makanan seperti saus olahan, pasta, ikan olahan, kopi dan makanan olahan; produk kosmetika seperti shampoo, produk perawatan rambut, produk perawatan kulit, bedak dan deodoran; serta produk obat-obatan yaitu produk yang mengandung vitamin A dan antibiotik [5]. Negara tujuan ekspor untuk produk makanan dan kosmetik adalah Malaysia, Arab Saudi dan Uni Emirat Arab, sedangkan untuk produk obat-obatan terbanyak diekspor ke Nigeria, Malaysia dan Arab Saudi.

Di sisi lain, Indonesia masih memiliki potensi untuk mengembangkan produk halal serta peluangnya masih terus meningkat. Berdasarkan data The State of Global Islamic Economy Report 2019/2020, pengeluaran konsumen muslim untuk makanan halal meningkat 3,1\% di tahun 2019, dari sebelumnya USD 1,13 triliun di 2018 menjadi USD 1,17 triliun dan diperkirakan akan meningkat menjadi USD 1,38 triliun pada tahun 2024. Potensi pengembangan industri halal di Indonesia sebenarnya sangatlah besar, hal ini karena beberapa faktor pendukung antara lain besarnya jumlah penduduk Indonesia, pertumbuhan industri halal lainya seperti sektor keuangan, dan pariwisata [26].

Selain itu, Menteri Keuangan juga menyampaikan bahwa total nilai potensi ekspor makanan halal Indonesia baru mencapai US\$229 juta dan jumlah ini dapat ditingkatkan lagi seiring meningkatnya kebutuhan makanan masyarakat muslim dunia [7]. Hal ini karena banyak produk makanan Indonesia seperti margarine, wafer, biskuit, nanas olahan, kopi kemasan, ekstrak kopi, ekstrak malt, saus, makanan bayi, roti dan kue merupakan produk yang sering 
dikonsumsi oleh negara OKI yang mayoritas memiliki penduduk muslim. Oleh sebab itu, Indonesia perlu fokus dalam pengembangan produk halal untuk memenuhi kebutuhan konsumen global.

b. Adanya pesaing dari negara non-muslim yang mengembangkan industri halal

Produk halal yang menjadi konsumsi masyarakat muslim, tidak hanya diproduksi oleh negara muslim. Fathoni dan Syahputri [26] menyampaikan bahwa terdapat 2 tantangan dalam mengembangkan industri halal Indonesia yaitu dari sisi eksternal dan internal, dimana salah satu faktor eksternalnya adalah adanya beberapa negara Islam lainnya yang menjadi pesaing seperti Malaysia. Bahkan banyak produk muslim yang justru diproduksi dan dieskpor oleh negara yang mayoritas penduduknya non-muslim. Sebagai contoh, eksportir terbesar makanan halal masih dipegang oleh Brazil, Thailand dan Republik Rakyat Tiongkok (RRT) dengan pangsa pasar masing-masing sebesar 10,51\%, 8,15 \% dan 4,97\% [21]. Produk halal yang diekspor ke negara OKI banyak diproduksi oleh negara yang minoritasnya Muslim, seperti Brazil, Amerika Serikat, dan Australia [27]. Hal ini mempengaruhi perspektif masyarakat global bahwa halal merupakan isu internasional dan bukan hanya untuk masyarakat muslim saja.

Selain itu, beberapa negara non-OKI juga bermitra dengan negara yang mayoritas berpenduduk muslim seperti Brazil dan Uni Emirat Arab guna memasarkan produknya ke pasar halal yang sedang berkembang. Beberapa perusahaan multinasional juga berinvestasi untuk pengembangan produk halal. Salah satu contohnya adalah Ajinomoto, perusahaan penyedap rasa dari Jepang, dilaporkan menanamkan modalnya ke perusahaan Malaysia untuk memproduksi makanan halal. Menurut data The State of Global Islamic Economy Report 2019/2020 Indonesia, Malaysia, dan Uni Emirat Arab merupakan negara yang mendapat investasi tertinggi dalam ekonomi Islam, dan makanan halal merupakan salah satu sektor yang mendapatkan investasi tertinggi [3]. Potensi peningkatan permintaan makanan halal yang semakin besar telah mendorong banyak negara untuk memproduksi dan mengekspor makanan halal. Oleh karena itu, persaingan antar negara pengekspor produk halal menjadi semakin ketat, sehingga diperlukan strategi dalam memenangkan persaingan.

\section{c. Kurangnya pemahaman pelaku UMKM tentang pentingnya sertifikasi halal}

Beberapa pelaku UMKM masih belum menyadari pentingnya sertifikasi halal, padahal sertifikasi halal dapat meningkatkan nilai jual produk dan daya saing produknya di pasar global. KADIN [28] menyebutkan bahwa salah satu tantangan dalam pengembangan produk halal di pasar global adalah kurangnya pemahaman dari pelaku UMKM tentang potensi produk halal serta perlunya sertifikasi halal yang dapat meningkatkan pertumbuhan bisnisnya. Padahal sertifikasi halal telah diterima oleh masyarakat dunia sebagai suatu standar produk yang perlu dipenuhi untuk memastikan jaminan kehalalannya.

Selain itu, sebagian masyarakat juga kurang memiliki awareness tentang konsep halal sehingga hal ini berpengaruh pada pengembangan industri halal [26]. Menteri Perdagangan juga menyampaikan bahwa $90 \%$ makanan dan produk yang beredar di Indonesia sudah halal, namun demikian banyak yang belum memiliki sertifikat halal atau bahkan belum mengurusnya. Oleh karena itu, pengurusan sertifikasi halal perlu dipermudah agar semakin banyak pelaku usaha yang mengurusnya [29]. 


\section{Strategi Peningkatan Ekspor Produk Halal}

Dengan potensi dan peluang peningkatan permintaan produk halal yang terus berkembang seiring meningkatnya populasi muslim dunia, maka beberapa strategi yang perlu dilakukan dalam rangka meningkatkan ekspor produk halal Indonesia adalah:

\section{a. Peningkatan daya saing produk halal Indonesia}

Untuk dapat memenangkan persaingan di industri halal global, produk yang dihasilkan harus memiliki daya saing yang tinggi. Berdasarkan hasil penelitian yang dilakukan oleh A'yun [30], produk ekspor Indonesia masih memiliki daya saing untuk bisa berkompetisi dengan produk negara ASEAN lainnya. Salah satu produk unggulan berdaya saing Indonesia adalah kopi, sedangkan produk yang paling kurang berdaya saing adalah buah-buahan dan kacang. Saat ini komoditas kopi merupakan barang bebas ekspor, seiring dengan terbitnya Peraturan Menteri Perdagangan No. 19 Tahun 2021 Tentang Kebijakan dan Pengaturan Ekspor yang menghapus ketentuan tentang Eksportir Terdaftar (ET) Kopi, sehingga pelaku usaha dapat langsung mengekspor kopi ke mancanegara. Berdasarkan data BPS, nilai ekspor kopi di tahun 2020 sebesar USD 809 juta atau turun sekitar 7\% dibandingkan tahun lalu yang mencapai USD 872juta. Namun demikian, secara volume ekspor kopi mengalami kenaikan dari sebelumnya sebanyak 355.766ton menjadi 375.555 ton di tahun 2020 [5].

Salah satu upaya dalam meningkatkan daya saing produk adalah dengan mengembangkan penelitian agar tercipta produk halal berkualitas. Wakil Presiden RI, KH Ma'ruf Amin [31] menyampaikan bahwa beberapa langkah strategis dalam upaya meningkatkan ekspor produk halal adalah: memperkuat riset bahan dan material halal untuk menghasilkan produk halal berkualitas, membangun Kawasan Industri Halal $(\mathrm{KIH})$ dengan menyediakan insentif dan regulasi pendukungnya, dan membangun Sistem Informasi Manajemen Perdagangan Produk Halal yang memuat data dan informasi produk yang telah teregistrasi halal. Pembangunan halal center sebagai pusat penelitian dan pengembangan produk halal dapat menjadi salah satu strategi yang dapat dilakukan untuk pengembangan industri produk halal. Selain itu, prinsip ketertelusuran dalam rantai pasok halal dapat membuat produk indonesia lebih berdaya saing dan dapat diterima oleh negara lain, terutama negara anggota OKI [32].

Penerapan sertifikasi halal juga dapat meningkatkan daya saing produk halal. Komite Nasional Keuangan Syariah [33] juga tengah mendorong strategi nasional yaitu peningkatan halal awareness kepada masyarakat luas agar masyarakat selaku konsumen maupun produsen makanan dan minuman, dapat lebih memperhatikan sertifikasi halal. Selain itu, penerapan sertifikasi halal tidak hanya akan meningkatkan ekspor Indonesia namun juga dapat memenuhi kebutuhan masyarakat khususnya penduduk muslim dunia [30]. Oleh karena itu, diharapkan pemerintah dapat mendukung peningkatan ekspor produk halal Indonesia dengan pemberian literasi kepada pelaku Usaha Mikro Kecil dan Menengah (UMKM) tentang sertifikasi halal. Selain itu, pemerintah juga dapat memberikan bantuan dan pendampingan kepada pelaku UMKM untuk dapat meningkatkan kualitas produk, desain dan pengemasan produk halal, agar produk yang dihasilkan menjadi lebih menarik.

b. Memaksimalkan akses pasar ekspor produk halal

Potensi pasar industri halal dunia diperkirakan akan terus meningkat. Menurut data dari The State of the Global Islamic Economy Report 2020-2021, total pengeluaran umat muslim dunia di tahun 2019 mencapai sekitar USD 2,02 milyar, yang dibelanjakan untuk kebutuhan di sektor 
makanan, farmasi, kosmetik, fashion, pariwisata, dan sektor-sektor syariah lainnya, dan diperkirakan jumlahnya akan mencapai USD 2,3 triliun di tahun 2024 [3]. Hal ini didorong oleh kebutuhan masyarakat dunia akan produk halal, tidak hanya masyarakat muslim, namun telah menjadi tren gaya hidup dan berpengaruh terhadap perdagangan global.

Namun demikian, sebagian pelaku UMKM masih kesulitan untuk mendapatkan informarsi tren permintaan pasar, dan peluang pasar di luar negeri, sehingga mencari-cari calon pembeli dari luar negeri. Oleh karena itu, pemerintah dapat membantu dengan menyediakan informasi peluang pasar ekspor dengan mengoptimalkan peran dari perwakilan pemerintah di luar negeri, yaitu Atase Perdagangan, Indonesian Trade Promotion Center, Kedutaan Besar Republik Indonesia dan Konsulat Jenderal Republik Indonesia. Perwakilan negara juga dapat mengatur pertemuan (business meeting dan business matching) dengan mengundang calon pembeli dari negara setempat dan pelaku UMKM, sehingga dapat terjadi transaksi perdagangan.

Selain itu, pemerintah dapat memfasilitasi pelaku usaha dalam mengembangkan usahanya dengan mengikutsertakan UMKM pada pameran perdagangan di luar negeri untuk dapat lebih memperkenalkan produk halal Indonesia di pasar internasional. Salah satunya adalah World Dubai Expo 2021 yang diselenggarakan pada bulan Oktober 2021 hingga Maret 2022. Untuk dapat meningkatkan akses pasar produk halalnya di pasar global, pelaku usaha juga dapat memanfaatkan perjanjian perdagangan internasional yang telah disepakati, seperti ASEAN Trade in Goods Agreement (ATIGA) dan ASEAN-China Free Trade Agreement, untuk mendapatkan preferensi tarif, sehingga produk halal Indonesia dapat mengajukan pengurangan atau pembebasan tarif bea masuk di negara tujuan ekspor. Preferensi tarif tersebut dapat diajukan dengan menyerahkan dokumen Surat Keterangan Asal (SKA) yang menyatakan bahwa produk tersebut merupakan barang yang berasal, dihasilkan dan atau diolah dari Indonesia [6].

c. Mendukung UMKM ekspor dalam rantai pasok global

Dalam Masterplan Ekonomi Syariah Indonesia 2019-2924 disebutkan bahwa salah satu strategi utama untuk mendorong ekspor produk halal Indonesia semakin berkembang adalah dengan meningkatkan kapasitas UMKM agar menjadi bagian dari global value chain atau rantai pasok global industri halal. Penguatan UMKM ini dapat dilakukan melalui 4 (empat) program utama antara lain: (i) pemberian edukasi kepada pemilik usaha mikro, (ii) pemberian fasilitas pembiayaan, (iii) pembangunan database UMKM, dan pemberian literasi kepada UMKM [34]. Hal ini penting untuk memacu pertumbuhan usaha UMKM tersebut dan meningkatkan ketahanan ekonomi. Dengan mempertimbangkan hal tersebut, perlu dibangun pusat inkubasi bisnis di beberapa daerah sebagai tempat pembinaan dan pelatihan, yang dapat membantu UMKM untuk dapat menjadi bagian dari rantai nilai industri halal. The International Trade Center juga menekankan bahwa pelaku UMKM dapat berpartisipasi dalam rantai pasok global di sektor halal, karena potensi pertumbuhan makanan halal yang semakin besar [24].

Selain itu, beberapa strategi lainnya yang dapat dilakukan untuk pengembangan industri produk halal adalah peningkatan kemampuan sumber daya manusia yang memiliki keahlian di bidang sertifikasi dan produksi produk halal, meningkatkan edukasi dan komunikasi kepada masyarakat, dan mengembangkan keterlibatan pelaku usaha dalam jaringan perdagangan produk halal di pasar global atau global value chain [34]. Oleh sebab itu, keterlibatan UMKM 
dalam rantai pasok global perlu didorong dengan melakukan sinergi dengan perusahaan besar, dan memberikan pelatihan dan pendampingan untuk mendapatkan informasi terkait tren produk yang sedang digemari, akses pasar dan prosedur ekspor dan impor di negara tujuan ekspor produk halal.

\section{d. Optimalisasi penggunaan e-Commerce}

Salah satu strategi untuk dapat memaksimalkan peluang ekspor produk halal adalah dengan mengoptimalkan penggunaan e-commerce. Hal ini karena kemajuan digitalisasi telah mampu menembuh batas perdagangan antar negara. Direktur Jenderal Perdagangan Dalam Negeri Kementerian Perdagangan menyampaikan bahwa e-commerce dapat menjadi sarana promosi dan berdagang bagi pelaku UMKM karena adanya kemudahan transaksi dan menjadi salah satu solusi yang dapat digunakan untuk mengatasi dampak pembatasan ekonomi di masa pandemi [8]. Penggunaan e-commerce juga dapat memotong rantai distribusi sehingga dapat mengurangi biaya dan menjadikan harga produk lebih terjangkau.

Namun demikian, pemanfaatan e-commerce masih minim di kalangan pelaku UMKM. Kementerian Koperasi dan UKM menyampaikan bahwa hanya 13,7 juta atau 21\% dari total 64 juta UMKM yang memanfaatkan teknologi digital, oleh karena itu Kemenkop UKM menargetkan 30 juta pelaku usaha dapat terhubung dengan teknologi digital di tahun 2024. Selain itu, digitalisasi UMKM di Indonesia masih relatif rendah dibandingkan dengan negara lainnya [35]. Hal ini karena jumlahnya kurang dari 15\% dari total pelaku UMKM yang ada di Indonesia. Oleh sebab itu, pemerintah dapat mendorong pemanfaatan e-commerce dengan memberikan pelatihan, dan pendampingan kepada pelaku UMKM yang memproduksi produk halal agar dapat mengakses pasar digital. Hal ini penting agar produk halal buatan Indonesia dapat diekspor ke pasar global.

\section{Kesimpulan}

Dengan terbitnya Undang-Undang Nomor 33 Tahun 2014 tentang Jaminan Produk Halal, pemerintah berkomitmen untuk mendorong pengembangan industri halal. UU juga tersebut dimaksudnya untuk memberikan perlindungan dan jaminan kehalalan suatu produk yang dikonsumsi oleh masyarakat. Selain itu, telah diterbitkan pula masterplan pengembangan ekonomi Syariah yang mencakup industri halal antara lain makanan dan minuman, produk kosmetik, obat-obatan, ekonomi syariah, fesyen, dan perjalanan wisata. Sehingga pemerintah menargetkan agar industri halal di Indonesia semakin maju dan berkembang serta Indonesia dapat menjadi pusat industri halal terdepan.

Sejak adanya pandemi covid-19, permintaan dunia atas produk halal menjadi berkurang. Namun demikian, permintaan akan produk halal seperti makanan, minuman, kosmetika, farmasi dan obat-obatan serta industri halal lainnya seperti fesyen, akan membaik dan diperkirakan akan meningkat di tahun 2024. Bahkan menurut data dari The State of Global Islamic Economy Report 2019/2020, potensi peningkatan pengeluaran konsumen muslim untuk makanan halal akan meningkat menjadi USD 1,38 triliun pada tahun 2024.

Namun demikian, Indonesia belum dapat memanfaatkan potensi tersebut karena beberapa tantangan antara lain (i) belum fokus dalam pengembangan produk halal, karena masih mengutamakan ekspor komoditas pertambangan dan perkebunan, (ii) adanya pesaing dari negara non-muslim yang mengembangkan industri halal seperti Brazil, Thailand dan Republik 
Rakyat Tiongkok, dan (iii) Kurangnya pemahaman pelaku UMKM tentang pentingnya sertifikasi halal yang membuat produk Indonesia kurang berdaya saing.

Oleh karena itu, dengan potensi dan peluang peningkatan permintaan produk halal yang terus berkembang seiring meningkatnya populasi muslim dunia, maka beberapa strategi yang perlu dilakukan dalam rangka meningkatkan ekspor produk halal Indonesia adalah (i) peningkatan daya saing produk halal indonesia dengan mengembangkan penelitian agar tercipta produk halal berkualitas serta penerapan sertifikasi halal, (ii) memaksimalkan akses pasar ekspor produk halal dengan dengan mengoptimalkan peran dari perwakilan pemerintah di luar negeri, mengikutsertakan UMKM pada pameran perdagangan di luar negeri dan memanfaatkan perjanjian perdagangan internasional yang telah disepakati, (iii) mendukung UMKM Ekspor dalam rantai pasok global dengan memberikan pelatihan dan pendampingan untuk mendapatkan informasi terkait tren produk yang sedang digemari, akses pasar dan prosedur ekspor dan impor di negara tujuan ekspor produk halal, dan (iv) optimalisasi penggunaan e-commerce dengan memberikan pelatihan, dan pendampingan kepada pelaku UMKM yang memproduksi produk halal agar dapat mengakses pasar digital. Hal ini penting agar produk halal buatan Indonesia dapat diekspor ke pasar global.

\section{Referensi}

[1] V. B. Kusnandar, "Katadata.co.id", Diakses: 6 February 2022. [Online]. Tersedia: https://databoks.katadata.co.id/datapublish/2021/11/03/rissc-populasi-muslimindonesia-terbesar-di-dunia.

[2] A. P. M. S. H. H. Sukoso, "Ekosistem Halal 2020", Departemen Ekonomi dan Keuangan Syariah Bank Indonesia, Jakarta, 2020.

[3] DinarStandard, "Laporan Ekonomi Islam Global 2020/2021," DinarStandard, 2020.

[4] Weforum, "covid19 pandemic trade services goods," How has the COVID-19 pandemic affected global trade?" [Online]. Tersedia: https://www.weforum.org/agenda/2021 /08/covid19-pandemic-trade-services-goods/ 2021.

[5] BPS, Berita Resmi Statistik Triwulan II 2020, 2020.

[6] K. Perdagangan, "Kementerian Perdagangan," Diakses: 2022. [Online]. Tersedia: https://e-ska.kemendag.go.id/home.php/home/form.

[7] Admin, "Bisnis.com," Diakses: 10 February 2022. [Online]. Tersedia: https://ekonomi.bisnis.com/read/20201024/9/1309419/dari-10-produk-saja-potensi -ekspor-makanan-halal-ri-bisa-capai-ratusan-juta-dolar.

[8] K. Tiofani, "Kompas.com," Diakses: 23 January 2022. [Online]. Tersedia: https://www. kompas.com/food/read/2021/09/22/091200675/apa-itu-makanan-halal-menurutmajelis-ulama-indonesia.

[9] Admin, "Indonesia Halal Training and Education Center (IHATEC)," 2021. [Online]. Tersedia: https://ihatec.com/pengertian-makanan-halal/.

[10] A. Apriyantono, Masalah Halal : Kaitan antara Syar'i, Teknologi dan Sertifikasi, PT Kiblat Buku Utama, 2005.

[11] K. S. Hasan, "Kepastian Hukum Sertifikasi dan Labelisasi Halal Produk Pangan", Jurnal Dinamika Hukum, vol. 14, no. 2, p. 227-238, 2014.

[12] Mukidi, "Prosedur Pemberian Sertifikat Label Halal Terhadap Produk Makanan Di Restoran Hotel Syariah Untuk Mewujudkan Hak Kenyamanan Konsumen Muslim 
(Studi Di Kementerian Agama Provinsi Sumatera Utara)," Jurnal Hukum Kaidah, vol. 19, no. 3, pp. 397-415, 2020.

[13] H. Merdesci, "Pangan Halal dan Cara Memilih Produk Kemasan yang Aman dan Halal," Jurnal Teknologi Pertanian, vol. 2, no. 2, pp. 31-41, 2013.

[14] S. K. R. Indonesia, "Jaringan Dokumentasi dan Informasi Hukum," Diakses: 3 Januari 2022 . [Online]. Tersedia: https://jdih.setkab.go.id /PUUdoc/176351/PP_Nomor_39_ Tahun_2021.pdf.

[15] M. F. M. Mohammad, "Pengaturan Sertifikasi Jaminan Produk Halal Di Indonesia," Kertha Wicaksana: Sarana Komunikasi Dosen dan Mahasiswa, vol. 15, no. 2, pp. 149157, 2021.

[16] M. S. Hidayatullah, "Sertifikasi dan Labelisasi Halal Pada Makanan Dalam Perspektif Hukum Islam (Perspektif Ayat Ahkam)," Yudisia : Jurnal Pemikiran Hukum dan Hukum Islam, vol. 11, no. 2, pp. 251-270, 2020.

[17] A. Kamsari, "Badan Penyelenggara Jaminan Produk Halal," Diakses: 02 February 2022. [Online].

Tersedia: http://halal.go.id/cms/assets/files/Materi_Pak_Amru_compressed

[18] Z. Ubaydilla dan M. S. Fathurohman, "Implementasi Halal Tracebility Supply Chain Dengan Model Supply Chain Operation Reference (SCOR) Industri Makanan Halal," Jurnal Ekonomi Syariah Teori dan Terapan, vol. 8, no. 5, pp. 617-629, 2021.

[19] K. S. Hasan, "Kepastian Hukum Sertifikasi dan Labelisasi Produk Halal," Jurnal Dinamika Hukum, vol. 14, no. 2, pp. 227-238, 2014.

[20] Syafrida, "Sertifikat Halal Pada Produk Makanan Dan Minuman Memberi Perlindungan Dan Kepastian Hukum Hak-Hak Konsumen Muslim," ADIL: Jurnal Hukum, vol. 7, no. 2, 2017.

[21] S. Ramalan, "Okezone.com," [Online]. Tersedia: https://economy.okezone.com/read/ 2020/10/24/320/2298876/ekspor-indonesia-ke-negara-oki-diacungi-jempol-tapi.

[22] W. L. Neuman, "Social Research Methods: Qualitative and Quantitative Approaches", USA: Pearson, 2014.

[23] N. W. Lawrence, "Social Research Methods", Boston: Allyn and Bacon, 2014.

[24] The International Trade Centre,"From Niche to Mainstream" Tersedia: 15 Januari 2022. [Online]. Tersedia: https: //www.intracen.org/uploadedFiles/intracenorg /Content/Publications/Halal_Goes_Global-web(1).pdf.

[25] BPS, "Berita Resmi Statistik Triwulan IV 2021", 2021.

[26] BPS, "Berita Resmi Statistik Triwulan III 2020", 2020.

[27] T. H. S. M. A. Fathoni, "Potret Industri Halal Indonesia: Peluang dan Tantangan", Jurnal IImiah Ekonomi Islam, vol. 6 , pp. 428-435., 2020.

[28] I. D. Ana, "Wapresri.go.id", Diakses: 5 Februari 2022. [Online]. Tersedia: https://www. wapresri.go.id/kuasai-pasar-halal-dunia-indonesia-perlu-perkuat-riset-produk-halal/.

[29] KADIN, "Indonesia Halal Products In The Global Market Competition" [Online]. Tersedia: https://isef.co.id/wp-content/uploads/2019/11/INHALIFE-2019-.pdf.

[30] D. P. A. Yustinus, "Bisnis.com", Diakses: 03 Februari 2022. [Online]. Tersedia: https:// ekonomi.bisnis.com/read/20201031/12/1311740/indonesia-incar-negara-okisebagai-tujuan-ekspor-potensial.

[31] Q. A'yun, "Comparative Analysis of Potential Halal Product Exports of Indonesia In Asean Countries," Jurnal Fidusia, vol. 4, 2021.

[32] M. Amin, "Wapresri.go.id," [Online]. Tersedia: https://www.wapresri.go.id/kuasaipasar-halal-dunia-indonesia-perlu-perkuat-riset-produk-halal/. 
[33] N. Masruroh, "The Competitiveness of Indonesian Halal Food Exports in Global Market Competition Industry", Jurnal Ekonomi Islam, vol. 11, no. 1, pp. 25 - 48 , 2020.

[34] "Komite Nasional Keuangan Syariah," 2020. [Online]. Tersedia: http://iaiglobal.or.id/v03/files/file publikasi/panel.

[35] K. P. P. N. B. P. P. Nasional, "Masterplan Ekonomi Syariah Indonesia 2019-2024," 2018.

[36] S. H. Situmorang, "The Challenges of FinTech Inclusion and Digitization of SMEs in Indonesia," in FinTech Development for Financial Inclusiveness, pp. pp.118-134, 2022. 